\title{
Hostages of Rome
}

\author{
By Simon Thijs*
}

These preliminary thoughts on my doctoral dissertation aim to clarify the exact meaning of the Latin word obses-in particular in contrast to the Greek 'óp Although hostage taking might not always have secured treaties successfully, it was a common practice for centuries as it served other purposes. Roman generals presented hostages as proof of their military and diplomatic accomplishments and thus strengthened their position within the Roman nobilitas. Nevertheless, hostage taking was an important institution in Roman international relations because it went hand in hand with the concept of fides- thus personifying trustworthiness-and could obviously fulfill its "traditional" role of providing leverage, especially in dealing with "barbaric" people. The Romans did not use it to Romanize foreign princes and leaders. In taking a close look at the case of the Seleucid Demetrius, it becomes clear that this happened more or less unintentionally and was not a primary objective.

\section{Introduction}

In recent months and years, hostage situations have been featured heavily in the media. Reports of terrorists and other criminals taking hostages have become a very common part of the news. However, a century or so ago, hostage taking was a common practice for military and state agents. Older editions of the Encyclopaedia Britannica defined the term thusly: "Hostage, in war, a person handed over by one of two belligerents to the other, or seized as security for the carrying out an agreement or for preventing violation of the law of war." This definition has approximately the same meaning "hostage" had in ancient times. It may even be that the word "hostage" derives from the Latin obses. ${ }^{1}$

\section{Meaning}

In the context of Roman interstate relations, obses is a technical term used to describe hostages provided voluntarily by one party to another-following the terms of an agreement - to serve as sureties or pignus fidei for their giver's faith. ${ }^{2}$ They are clearly distinguished from hostages taken by violence. The

* PhD Student, Philipps-University Marburg, Germany.

1. Moscovich, The Role of Hostages, 30.

2. C. L. Walker, "Hostages in Republican Rome" ( $\mathrm{PhD}$ diss., University of North Carolina at Chapel Hill, 1980), 19. For an overview of older scholarship on legal hostages see P. Kehne, "Geiselstellungen im römischen Völkerrecht und der Außenpolitik des Prinzipats" ["Hostage Delivering in Roman International Law and in Foreign Policy under the Principate"], Marburger Beiträge zur Antiken Handels-, Wirtschafts- und Sozialgeschichte 30 (2012), 199-254. 
sources support this view: Frontinus, for example, avoids the term in connection with the Roman legati captured by unnamed civitates to force the release of their own obsides. Instead, Frontinus called the illegally taken Romans contraria pignora. ${ }^{3}$ Nevertheless, a few cases exist where obses was used to describe hostages that were not provided by mutual agreement. For example, the young men who served as garrison in Carthage and provided surety for the trustworthiness of their compatriots are called obsides by Livy, ${ }^{4}$ as are the Syracusan soldiers kept as hostages by the Carthaginian generals Hippocrates and Epicydes, ${ }^{5}$ and the Achaean soldiers demanded by Philipp V under a pretext. ${ }^{6}$ Nevertheless, Livy relied on a Greek source, namely Polybius, for these three stories. ${ }^{7}$ Here he found the word 'ó $\mu \eta \rho$ s (as in Polybius III, 33, 13) and translated it using obses although the Greek word has a much broader meaning: in contrast to the Latin term it also denotes hostages taken without

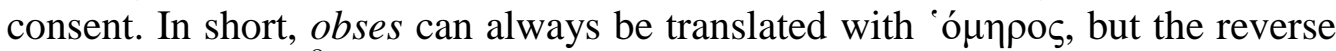
is not always true. ${ }^{8}$

\section{Agreements Involving Hostages}

\section{Short-term Agreements}

When exactly did Rome make use of such "formal" or "legal" hostages? They were utilized in all cases of ending or pausing war. First of all, shortterm, tactical agreements must be mentioned. These include parlays (conloquium), ${ }^{9}$ armed truces (indutiae), and preliminary contracts or guarantees $\left(\right.$ sponsio ${ }^{10}$ subject to approval by the senate. These seem to be the most natural occasions to provide hostages.

\section{Foedera}

Still, the Romans took more hostages following the terms of foedera, although Livy explicitly states that Roman foedera did not include hostages. Indeed, there is no evidence of this before the end of the Hannibalic War. But afterward, Rome demanded hostages from several extra-Italian contracting

\footnotetext{
3. Frontinus, Strategemata. I, 8, 6 .

4. Livy XXI, 21,13.

5. Livy XXIV, 31, 12.

6. Livy XXXI, 25, 8.

7. U. Händl-Sagawe, Der Beginn des 2. Punischen Krieges: ein historisch-kritischer Kommentar zu Livius Buch 21 [The Beginning of the Second Punic War: A Historical and Critical Commentary on Livy Book 21] (München: Münchener Universitätsschriften, 1995), 137 for the sources of Livy XXI, 21, 13. A. Klotz, Livius und seine Vorgänger [Livy and his Predecessors] 1 (Stuttgart: Verlag B.G. Teubner, 1940), 113 and 2-4 for the sources of Livy XXIV, 31, 12 and XXXI, 25, 8.

8. Walker, Hostages in Republican Rome, 1.

9. Livy XLII, 38.

10. For a list of most agreements from Republican times see Walker, Hostages in Republican Rome, 215-259.
} 
parties: The Second Punic War ended with a treaty that included hostage exaction; ${ }^{11}$ the Treaty of Apamea contained stipulations concerning hostages to be delivered to Rome and exchanged every three years; ${ }^{12}$ the Aetolians concluded a peace treaty secured by hostages. ${ }^{13}$ This may relate to Rome's development from a merely local power toward a Mediterranean one. Dealing with new partners from different cultural, religious and legal backgrounds required modifications to the old system. ${ }^{14}$ Besides, Rome aimed to create different relationships with those faraway states than it did with its direct neighbors. ${ }^{15}$

\section{Deditio}

By far the most hostages came under Roman control as part of formal surrender (deditio). The defeated state-if its deditio was accepted-usually had to surrender all its profane and sacred possessions as well as all arms, saw garrisons placed in its cities, had to provide hostages ${ }^{16}$ and technically ceased to exist. ${ }^{17}$ Whether the delivery of hostages, arms and other stipulations belonged to pacta preceding the acceptance of deditio or if they were part of the actual agreement, is debatable. ${ }^{18}$ In most cases, Rome would reinstate such dediticii, ${ }^{19}$ which might have been the expectation of the surrendering civitates. ${ }^{20}$ Fides inclined Rome toward mild treatment after deditio ${ }^{21}$ (hence the expression "deditio in fidem"), but annihilation of the defeated community was in theory legitimate. ${ }^{22}$ What kind of relationship Rome and reinstated civitates shared is not entirely clear.

11. Polybius XV, 18, 8. Livy XXX, 37, 6. Appian, Libyca 54. Cassius Dio XVII, 82.

12. Polybius XXI, 43, 22. Livy XXXVIII, 38, 15. Appian, Syriaca 39.

13. Polybius XXI, 32, 10-11. Livy XXXVIII, 11, 6.

14. C. Baldus, Regelhafte Vertragsauslegung nach Parteirollen im klassischen und römischen Recht und in der modernen Völkerrechtswissenschaft: zur Rezeptionsfähigkeit römischen Rechtsdenkens [Systematic treaty interpretation according to party affiliation in classical and Roman law and in modern international law: on the transferability of Roman legal thinking], Vol. 1, (Frankfurt am Main: Peter Lang, 1998), 200-204. M. J. Moscovich, The Role of Hostages in Roman Foreign Policy, (Open Access Dissertations and Theses. Paper 7770. McMaster University, 1972), 25f. W. Dahlheim, Struktur und Entwicklung des römischen Völkerrechts im dritten und zweiten Jahrhundert v. Chr [Structure and Development of Roman International Law during the Third and Second Century BC] (München: C.H. Beck, 1968), 174f.

15. Dahlheim, Struktur, 159-162.

16. Livy XXVIII, 34, 7.

17. K.-H. Ziegler, "Völkerrecht der Römischen Republik" ["International Law of the Roman Republic"] in Aufstieg und Niedergang der Römischen Welt I, 2, ed. Temporini, Hildegard (de Gruyter, Berlin/New York, 1972), 95.

18. D. Nörr, Aspekte des römischen Völkerrechts. Die Bronzetafel von Alcántara [Aspects of Roman International Law. The Bronze Plaque of Alcántara] (München: Verlag der Bayerischen Akademie der Wissenschaften, 1989), 41. Dahlheim, Struktur, 8.

19. Nörr, Aspekte, 51-65.

20. E. S. Gruen, "Greek Пí $\tau 1 \varsigma$ and Roman Fides," Athenaeum 60 (1982), 54.

21. Nörr, Aspekte, 90.

22. K.-J. Hölkeskamp, "Fides - deditio in fidem - dextra data et accepta: Recht, Religion und Ritual in Rom" ["Law, Religion and Ritual in Rome"], in The Roman Middle Republic. 
Amicitia

It may be that foedera were concluded afterward, ${ }^{23}$ but the most likely status is simple amicitia. ${ }^{24}$ It seems that states occasionally had to give hostages as proof of such amicitia even without contractual obligations. Otherwise, it is hard to explain the exaction of hostages from Arretium by Rome after the city's defection had been rumored during the Hannibalic War:

\section{Livy XXVII, 24, 1-3}

As regards the Arretines, reports grew more serious every day, and the anxiety of the senators had increased. Accordingly Gaius Hostilius received written orders not to postpone taking hostages from the Arretines, and Gaius Terentius Varro was sent with military authority, that Hostilius might turn them over to him to be escorted to Rome. Upon Varro's arrival, Hostilius at once ordered the one legion which was encamped before the city to advance into the city, and he posted his forces in suitable positions. Then, summoning the senate to the forum, he demanded hostages of them. When the senate asked for two days to consider, he ordered that they themselves furnish them forthwith, or else on the next day, he declared, he would take all the children of the senators. ${ }^{25}$

The next day, Varro took with him 120 of the senators' children and installed a garrison.

Arretium was not in a state of deditio because its own senate still governed it. Neither is it likely that Arretium was bound to give hostages by a foedus, ${ }^{26}$ because the Roman demand was debatable - as shown by the reaction of the senators. Furthermore, the Arretines were originally free to choose the hostages themselves, whereas in most foedera Rome selected the hostages. Certainly, the Romans' threatening attitude finally made the Arretines give in, but the demanding of hostages as such, obviously, did not infringe common practice.

Politics, Religion, and Historiography c. 400-133 BC (Rome: Institutum Romanum Finlandiae, 2000), 245.

23. Ibid., 247.

24. J. W. Rich, "Treaties, allies and the Roman conquest of Italy," in War and Peace in Ancient and Mediaeval History, ed. Philip de Souza (New York, NY: Cambridge University Press, 2008), 63. P. J. Burton, Friendship and Empire. Roman Diplomacy and Imperialism in the Middle Republic (353-146 BC) (New York, NY: Cambridge University Press, 2011), 117.

25. Translation: Gardner Moore, Livy with an English Translation in Fourteen Volumes VII (Cambridge, Mass.: Harvard University Press, 1958), 306-309.

26. Demanding hostages even years after conclusion of a foedus was in theory possible if obligations were not fulfilled, as in the case of the Illyrian King Pinnes, who was in default with his payments: Livy XXII, 33, 5. But in this case, although Arretium, like most cities in Etruria, probably had a foedus with Rome [see W. Harris, "Roman foedera in Etruria," Historia 14 (1965)] there was no such stipulation in the contract (A. J. Pfiffig, "Die Haltung Etruriens im 2. punischen Krieg" ["The Position of Etruria during the Second Punic War"], Historia 15 (1966), 201). 
The same may be true for the hostages of Thurii and Tarentum who were executed in $212 \mathrm{BC}$ after their failed attempt to escape from Rome. ${ }^{27} \mathrm{We}$ do not know of any deditio or foedus of either city at that time, but, as in Arretium, both were secured by a Roman garrison (if the garrisons had not been permanently stationed in Thurii and Tarentum since 225 or even before. ${ }^{28}$ In the case of Thurii at least, the Romans might have been invited into the town, as this had happened earlier. ${ }^{29}$ Even the Illyrian Penestaeexplicitly described as faithful friends - had to give hostages. ${ }^{30}$ We know that there were Roman garrisons in the towns of the Illyrian Penestae, as in the examples mentioned earlier. ${ }^{31}$ The connection between hostages and garrisons thus seems to be very important. As we have seen, they often went together. If the latter could be placed in friendly cities, then the former could be taken, too. $^{32}$

\section{Purposes of Hostage Taking ${ }^{33}$}

Looking at all these cases, it is striking that hostage taking was often not enough to secure peace. Rarely do we learn about any severe punishment of hostages when donor states were in breach of contract. ${ }^{34}$ Taking hostages thus seems quite pointless. However, it continued to be a widely used practice. Apparently, hostages served purposes other than security alone. ${ }^{35}$

27. Livy XXV, 7, 10-14.

28. M. P. Fronda, Between Rome and Carthage. Southern Italy during the Second Punic War (New York, NY: Cambridge University Press, 2010), 191 n. 12.

29. Appian, Samnitika 7, 1-2. Fronda, Between Rome and Carthage, 197f.; $226 \mathrm{f}$.

30. Liv. XLIII, 21, 2f.

31. Liv. XLIII, 18, 6-10.

32. Polybius XXVIII, 5 shows a further example of friendly people asking for a Roman garrison. Also, the people of Henna in Sicily declared that they had come into Roman societas voluntarily, but there was still a garrison in that town (Livy XXIV, 37, 3-7).

33. Walker, Hostages in Republican Rome, 1-10 says he will discuss "Meaning and Purpose of Hostageship," but only deals with the formal circumstances.

34. Ibid., 177-183 on revolts despite hostages. While Walker may be right in assuming that Rome executed more hostages than we know of, the examples presented are of little value: the Iberian horsemen imprisoned by Marcellus were not formal hostages (Appian, Hispanica 48), Sertorius' actions in Spain hardly reflect the normal conduct of Rome (Plutarch, Sertorius $10,3 ; 25,4)$ and the hostages of Cora and Pometia were only killed after the revolt had ended (Dionysius of Halicarnassus VI, 30, 1; see below on this case). See Moscovich, The Role of Hostages, $60 \mathrm{n}$. 70 for some cases of violated treaties secured by hostages.

35 . The theory of hostages securing only financial clauses (Täubler, Imperium Romanum, 1 n. 3; S. Elbern, "Geiseln in Rom" ["Hostages in Rome"], Athenaeum 78 (1990), 99-100) has already been rejected several times (A. Aymard, Les otages Carthaginois à la fin de la Deuxième Guerre Punique" ["The Carthaginian Hostages at the End of the Second Punic War"]. In Annales publiées par la Faculté des Lettres de Toulouse. Pallas. Études sur l'antiquité 1 (February 1905), 55; Moscovich, The Role of Hostages, 26; Walker, Hostages in Republican Rome, 7-8) and will not be discussed here again. 


\section{Proof of Fides}

First, the meaning of hostages in the context of fides must not be neglected. Scholars have studied fides at length and underlined its importance, as did ancient authors when they emphasized its omnipresence. ${ }^{36}$ Evidence from the first half of the third century BC further indicates that Rome was keen to demonstrate its own fides to the world. ${ }^{37}$ The high hopes the Aetolians put into deditio in fidem $^{38}$ are proof that belief in Roman fides was still strong in the second century among Mediterranean people ${ }^{39}$ and Rome handled it carefully and mostly abided by its norms. ${ }^{40}$

Hostages were closely tied to fides. They are often described as pignus fidei and, in the second century $\mathrm{AD}$, some believed that the word obsides derived from $o b$ fides. ${ }^{41}$ So if fides was perceived as something real and powerful and not merely an obscure idea, ${ }^{42}$ then hostages could be recognized as real proof of it. This interpretation is supported by a passage in Livy: when Hannibal managed to capture a number of Locrians, their relatives felt forced to vote for an alliance with the Carthaginians because they had pledged their goodwill as if they had given hostages (velut obsidibus datis pigneratos haberent animos). ${ }^{43}$ Although this was technically not a case of hostage taking, it describes what obsidibus datis meant: the symbol of the donor's inner will (animus) to fulfill the demands of the recipient, thus his honesty, faith or fides.

The same idea stands behind the Roman blame of the Thracian King Cotys after the Third Macedonian War: Cotys had come to Rome to ask for the release of his son Bithys and others who had been hostages at the Macedonian court and were then captured by Rome. Cotys claimed that by taking hostages, Perseus had forced him into an alliance. However, the Roman senators replied that these very same hostages were proof that he had joined their enemy by choice. They knew what these obsides truly represented: Cotys had voluntarily pledged his fides. ${ }^{44}$

Hostages might not make their donors stay faithful at all times-just as ancient states did not always live up to their own ideal of fides. Nevertheless, the continuous appealing to fides would not be abandoned just because it failed on occasion $^{45}$ - as did the use of hostages as pignora fidei.

\footnotetext{
fides.

36. See Hölkeskamp, "Fides" and Nörr, Aspekte, 102 n. 1 for sources and scholarship on

37. Burton, Friendship, 132-133. Hölkeskamp, "Fides," 236-238.

38. Polybius XX, 9, 9-10, 8.

39. Gruen, "Greek Пí $\tau \imath \varsigma, "$ 63. A further example is the worship of Roman fides in Greece (Plut. Flam. 16, 5).

40. Nörr, Aspekte, 103.

41. Moscovich, The Role of Hostages, 6-7.

42. Hölkeskamp, "Fides," 249.

43. Livy XXIV, $1,7$.

44. Livy XL, 42, 5-12.

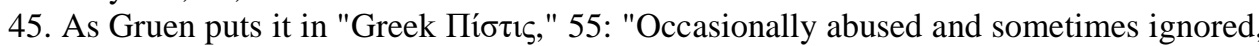
it nonetheless imposed moral restraints and engendered legitimate expectations."
} 


\section{"Romanization"}

Second, some scholars have pointed out that Rome used hostages to strengthen pro-Roman tendencies in the hostages' home countries. ${ }^{46}$ While hostage taking may have had this effect, it is unlikely that "Romanization" was an intentional process.

The locus classicus of a Romanized hostage is the case of Demetrius of Macedonia. The son of Philip V was one of the hostages delivered at the end of the Second Macedonian War, first as part of a truce, ${ }^{47}$ then according to the final agreement, ${ }^{48}$ and ultimately brought to Rome. After appearing in the triumph of Flaminius, ${ }^{49}$ he stayed in Rome until 191 BC, when he was sent home to reward his father's support of Rome in the war against Antiochus III. ${ }^{50}$ A few years later, he led an embassy that appeared before the senate in Rome, because Philip hoped to benefit from Demetrius' good relations with leading Romans. ${ }^{51}$ Although the senate rejected virtually everything Demetrius had to report, he was well treated, was complimented in the highest ways and maybe even had his hopes of becoming king raised. ${ }^{52}$ This treatment earned him a lot of envy in Macedonia and caused him to be murdered ${ }^{53}$ when he became a threat to his older brother Perseus ${ }^{54}$ and made himself suspicious in his father's eyes. ${ }^{55}$ It is obvious that Rome tried to influence the Macedonian court through Demetrius, but one should not jump to the conclusion that this was Rome's plan from the beginning. The senate only started to favor Demetrius publicly and underline his importance for Roman-Macedonian relations after he had led the embassy to Rome. It may have been on this occasion that the Romans realized the opportunity Demetrius presented. The same can be said for the Seleucid princes: both Antiochus IV and Demetrius I supported Rome after their respective ascendancies to the throne, but there is no proof that they were chosen as hostages in the hope of this occurring. On the contrary: Antiochus' release may not even have been Rome's idea, but that of Eumenes II. ${ }^{56}$ As for Demetrius I Soter, his release had been denied by the senate and he escaped against their will to become king. In addition, the princes educated at the court of Augustus and later used as client kings in the East had been sent to Rome voluntarily and thus were not real hostages. ${ }^{57}$ Furthermore, if Rome intended to create client kings, would it not have taken first-born sons who were bound to

46. Moscovich, The Role of Hostages, 39. Walker, Hostages in Republican Rome, 207209.

47. Polybius XVIII, 39, 5. Livy XXXIII, 13, 14. Zonaras IX, 16.

48. Livy XXXIII, 30, 10. Plutarch, Aratus 54, 2; Flamininus 9, 5. Eutropius IV, $2,1$.

49. Livy XXXIV, 52, 9. Plutarch, Flamininus 14, 2. Eutropius IV, 2, 2. Orosius IV, 20, 2.

50. Polybius XXI, 3, 3; 11, 9-10; Livy XXXV, 31, 5; XXXVI, 35, 13; XXXVII, 25, 12; Appian, Macedonica 9, 5; Appian, Syriaca 9, 20; 23; Eutropius IV, 3, 3.

51. Polybius XXII, 14, 9-10; Livy XXXIX, 35, 2-3; 47, 1-11.

52. Polybius XXIII, 3, 8 .

53. Polybius XXIII, 3, 9. Livy XL, 24, 4-8.

54. Livy XXXIX, 53, 1-11; XL, 5, 2.

55. Livy XL, 5, 8-9.

56. Mehl, "Eumenes II," 252. OGIS 248.

57. Monunmentum Ancyranum 32. 
become king? In the end, the "Romanization" of hostages and their political use must be viewed as a welcome but unintended side effect.

\section{Personal Fame}

A third point can be made by taking into account the person of the Roman commander in the field who actually received the hostages.

The Roman nobility was not a closed group; new men could earn their way in and others could drop out. ${ }^{58}$ The former could be achieved and the latter prevented only through performances such as military success and election to high office, but also using credit accumulated by ancestors. ${ }^{59}$ These achievements had to be presented in public ${ }^{60}$ in order to enlarge one's "symbolic capital," manifested in auctoritas or dignitas, ${ }^{61}$ and to surpass competitors in the race for leading positions. ${ }^{62}$

In this context, it appears that generals took personal pride and honor in exacting hostages. ${ }^{63}$ One of the oldest references to hostages in Roman history is the inscription on the sarcophagus of Scipio Barbatus that relates the leading away of hostages from Lucania and possibly other locations mentioned in the text. ${ }^{64}$ Seemingly, apart from his victories, the most notable accomplishment in Scipio Barbatus' career was the taking of hostages. Equally important was the display of hostages during triumphal processions, ${ }^{65}$ the most distinguished position being right in front of the victorious commander together with highranking captives. ${ }^{66}$ While results of battles (e.g., the captured enemy soldiers

58. K.-J. Hölkeskamp, "Conquest, Competition and Consensus. Roman Expansion in Italy and the Rise of the Nobilitas," Historia 42 (1993), 14.

59. K.-J. Hölkeskamp, Die Entstehung der Nobilität. Studien zur sozialen und politischen Geschichte der Römischen Republik im 4. Jhdt. v. Chr [The Creation of the Nobiles. Studies in Social and Political History of the Roman Republic in the Fourth Century BC] (Stuttgart: Franz Steiner Verlag Wiesbaden GmbH, 1987), 209-210.

60. V. Dementyewa, "Die römische 'Meritokratie' und die Entwicklung politischer Repräsentation" ['Roman 'Meritocracy' and the Development of Political Representation"] in Volk und Demokratie im Altertum (Göttingen: Edition Ruprecht, 2010), 112.

61. K.-J. Hölkeskamp, Rekonstruktionen einer Republik [Reconstructions of a Republic] (München: Oldenbourg Wissenschaftsverlag GmbH, 2004), 93-95.

62. Hölkeskamp, "Conquest," 25-26.

63. J. Allen, Hostages and Hostage-Taking in the Roman (New York, NY: Cambridge University Press, 2006), 95-125.

64. CIL VI 1284.1285. Latest edition: J. Fugmann and A. Kolb, Tod in Rom. Grabinschriften als Spiegel römischen Lebens [Death in Rome. Funerary Inscriptions as Mirrors of Roman Life] (Mainz am Rhein: Verlag Philipp von Zabern, 2008), 44-47.

65. Naturally, the more prominent the hostages were, the bigger the general's fame.

66. Livy XXXIV, 52, 9. Appian, Mithridatica 117. Plutarch, Pompeius 45, 4. Several descriptions of other triumphs do not mention hostages explicitly, but it may be assumed that they were present: Livy XXXVII, 59, 5 lists 32 generals, prefects and nobles in the triumph of Scipio over Antiochus without calling them hostages or captives; perhaps the 20 hostages from the treaty of Apamea (including Antiochus' son) were among them. In XXXVI, 40, 11 Livy reports that Publius Cornelius Scipio led prisoners of high rank in his Boian triumph. A few lines earlier $(40,4)$ he states that hostages had been taken from them; surely they were presented in the procession. Appian, Mithridatica 117 mentions satraps, sons and generals of 
and weapons) took up the first part of triumphs, the obviously more prestigious results of successful diplomacy (namely hostages as proof of deditio or foedera and precious personal gifts from other states) followed as highlights. Polybius reflects this in a passage that puts conquest by diplomatic means over victories in the field: the former belong entirely to the commander while the latter represent the work of the subordinates. ${ }^{67}$ Besides, hostages were a clear indication that war was definitely over, since they were a sign of deditio or a treaty favoring Rome. On the one hand, this signaled relief for the people, ${ }^{68}$ and on the other, it took away the opportunity for others to succeed in the same field as the triumphant general. ${ }^{69}$ In other words, hostages equaled peace, and that peace was something Rome granted a defeated opponent. ${ }^{70}$ Rome could deny this peace if there were no hostages, i.e., no proof of final victory. Rome rejected Quintus Minucius' request for triumph following his campaign in Liguria and against the Boians because he had no pignora to prove his success. ${ }^{71}$ He ended up organizing and paying for his own triumph from Mons Albanus while his colleague Gaius Cornelius held a regular triumph to celebrate his victory over the Insubrians and Cenomani. ${ }^{72}$ The interesting thing is that the description of Cornelius' triumph mentions a large number of Gallic nobles marching in front of the triumphant consul, whereas Minucius' triumph apparently featured only spoils of war. ${ }^{73}$ Dionysius from Halicarnassus alludes to the same connection between triumph and hostages on two occasions: in 478 BC, the consul Lucius Aemilius concluded a peace with the Veientes by taking neither land nor money nor hostages. Thereupon the senate opposed his triumph. ${ }^{74}$ Another account makes the allusion less direct. In the early fifth century BC, the Volscians surrendered to the consul Servilius and gave 300 hostages. As soon as the Roman army had retreated, the Volscians took up arms again and continued fighting until their final defeat. As a result, the other consul Appius Claudius ordered the execution of the Volscian hostages received by his colleague as a warning to others. Then he accused his colleague Servilius of having brought no spoils of war to the public treasury and tried to prevent his triumph. ${ }^{75}$ While the link is not made explicitly, it is peculiar that Appius Claudius first killed the hostages who might have enlarged Servilius' fame and then went on to deny his right to triumph. Maybe incidents of this

the kings in Pompeius' Mithridatic triumph; some were captives, some hostages. A number are called by name, but without clarifying their respective statuses.

67. Polybius V, 12, 2-4.

68. Polybius XVI, 23, 5 .

69. We know that Roman commanders were anxious about ending wars quickly so that their successor could not snatch the laurels from them: Polybius XVIII, 39, 4. Livy XXX, 36, 11. In Polybius III, 33-35, 1 the new consuls reversed this tendency when they refused the deditio by the Insubrians so that they themselves could earn a victory.

70. C. A. Barton, "The Price of Peace in Ancient Rome," in War and Peace in the Ancient World, ed. Kurt A. Raaflaub Malden (MA: Blackwell Publishing Ltd., 2007), 247.

71. Livy XXXIII, 22, 8 .

72. Livy XXXIII, 23, 4-8.

73. Livy XXXIII, 23, 8-9.

74. Dionysius IX, 17, 3-4.

75. Dionysius VI, 25, 2; 30, 1. 
sort were the reason for a law recorded in the Digesta $(48,4,1)$ that prohibited the killing of hostages without the Emperor's command. ${ }^{76}$ In addition, one could point to Caesar's comments about his campaigns in Gaul and the large numbers of hostages he reported to Rome. It was presumably an attempt to dispel doubts about his victories. ${ }^{77}$

As shown, Roman commanders probably had a personal interest in taking hostages that might be another reason for the continuity of the practice.

\section{Leverage}

Finally, it must not be forgotten that hostage taking could of course very well constrain the donor. Thus in 189 BC, a Roman consul tried to force the seditious inhabitants of Same into surrender by openly threatening hostages. Likewise, Aeneas Tacticus advises cities that have provided hostages to remove their parents and relatives in case the city is under attack, so they would not turn on their hometown when eye to eye with their threatened children.

Furthermore, Rome frequently reacted to seditions by demanding additional obsides as a punishment. This can only mean that in their eyes more hostages equaled more security. ${ }^{78}$ More proof can be found in Suetonius' Life of Augustus, where he states that Augustus exacted women from some barbarians because they were more effective. ${ }^{79}$ If hostages were purely symbolic, it would not matter if they were male or female. Celtic people in particular seem to have been anxious about hostages. There are known instances of Gauls trying to free hostages by force. ${ }^{80}$ Apparently, they were afraid that they might be mistreated ${ }^{81}$ and were particularly affected when their sons and nephews were in custody. ${ }^{82}$ Still, admittedly, this was not sufficient to prevent rebellions. ${ }^{83}$ Finally, pressure could be occasionally applied not by threatening a hostage but by the possibility of releasing him, as in the case of Antiochus IV, to whom the return of Demetrius as a possible claimant to the throne would have been a much bigger problem than his detention and death. ${ }^{84}$

76. Allen, Hostages, S. 119f.

77. S. NDiaye, "Le recours aux otages à Rome sous la République" ["The Use of Hostages in Republican Rome"], Dialogues d' Histoire Ancienne 21, no. 1 (1995), 163. Allen, Hostages, S. 112-115.

78. Moscovich, The Role of Hostages, 56 n. 27.

79. Suetonius, Augustus 21, 2.

80. Caesar, Bellum Gallicum III, 8, 2. Polybius III, 40, 10; Frontinus, Strategemata I, 8, 6 probably refers to the same incident.

81. Reports of Gauls mistreating hostages might also be a Roman exaggeration to discredit the barbarians.

82. Caesar, Bellum Gallicum V, 27, 2.

83. Even shortly after hostages were taken, rebellions could take place. See A. Matthaei, "Das Geiselwesen bei den Römern" ["Roman Use of Hostages"] Philologus 64 (Jan. 1905), 236 n. 40.

84. B. Scolnic, "Antiochus IV and the Three Horns in Daniel 7," Journal of Hebrew Scriptures 14 (2014), 16. 


\section{Summary}

Hostage taking was a common feature throughout Roman history as part of not only formal agreements like deditio and foedus, but also of interstate amicitia. The latter in particular indicates how closely connected obses and fides are. Fides may not have been a juridical institution but was still real and powerful, and in the same way obsides, too, were not purely symbolic in their meaning, but taken seriously as pignora fidei. Besides, hostages contributed to a Roman commander's prestige and played a key role in the triumphal procession as physical evidence of the peace attained through the general's personal achievements. Furthermore, just as one would expect in the light of modern understandings of hostage taking, control of hostages could also force the donor to keep peace, though Rome seems to have relied on this mostly in its dealings with less "civilized" communities like Gauls and other barbarians. In contrast, "Romanization" of hostages with the aim of placing "converts" back in their homelands does not appear to have been a primary objective and happened rather coincidentally.

Hostage taking proved to be effective in more than one way and Rome was very flexible in applying the concept to different circumstances, which clarifies why this institution persisted throughout centuries.

\section{Bibliography}

Allen, J. Hostages and Hostage-Taking in the Roman. New York, NY: Cambridge University Press, 2006.

Aymard, A. "Les otages Carthaginois à la fin de la Deuxième Guerre Punique" ["The Carthaginian Hostages at the End of the Second Punic War"]. In Annales publiées par la Faculté des Lettres de Toulouse. Pallas. Études sur l'antiquité 1 (February 1905), 44-63.

Baldus, C. Regelhafte Vertragsauslegung nach Parteirollen im klassischen und römischen Recht und in der modernen Völkerrechtswissenschaft: zur Rezeptionsfähigkeit römischen Rechtsdenkens [Systematic treaty interpretation according to party affiliation in classical and Roman law and in modern international law: on the transferability of Roman legal thinking], Vol. 1, Frankfurt am Main: Peter Lang, 1998.

Barton, C. A. "The Price of Peace in Ancient Rome." In War and Peace in the Ancient World, edited by Kurt A. Raaflaub Malden. MA: Blackwell Publishing Ltd., 2007, 245-255.

Burton, P. J. Friendship and Empire. Roman Diplomacy and Imperialism in the Middle Republic (353-146 BC). New York, NY: Cambridge University Press, 2011.

Dahlheim, W. Struktur und Entwicklung des römischen Völkerrechts im dritten und zweiten Jahrhundert v. Chr [Structure and Development of Roman International Law during the Third and Second Century BC]. München: C.H. Beck, 1968.

Dementyewa, V. "Die römische 'Meritokratie' und die Entwicklung politischer Repräsentation" ['Roman 'Meritocracy' and the Development of Political 
Representation"]. In Volk und Demokratie im Altertum. Göttingen: Edition Ruprecht, , 2010, 107-142.

Elbern, S. "Geiseln in Rom" ["Hostages in Rome"]. Athenaeum 78 (1990), 97-140.

Fronda, M. P. Between Rome and Carthage. Southern Italy during the Second Punic War. New York, NY: Cambridge University Press, 2010.

Fugmann, J. and A. Kolb. Tod in Rom. Grabinschriften als Spiegel römischen Lebens [Death in Rome. Funerary Inscriptions as Mirrors of Roman Life]. Mainz am Rhein: Verlag Philipp von Zabern, 2008.

Gardner Moore, F. Livy with an English Translation in Fourteen Volumes VII. Cambridge, Mass.: Harvard University Press, 1958.

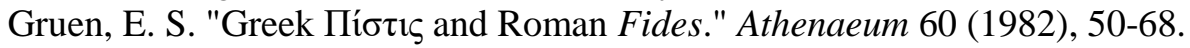

Händl-Sagawe, U. Der Beginn des 2. Punischen Krieges: ein historisch-kritischer Kommentar zu Livius Buch 21 [The Beginning of the Second Punic War: A Historical and Critical Commentary on Livy Book 21]. München: Münchener Universitätsschriften, 1995.

Harris, W. "Roman foedera in Etruria." Historia 14 (1965), 282-292.

Hölkeskamp, K.-J. Die Entstehung der Nobilität. Studien zur sozialen und politischen Geschichte der Römischen Republik im 4. Jhdt. v. Chr [The Creation of the Nobiles. Studies in Social and Political History of the Roman Republic in the Fourth Century BC]. Stuttgart: Franz Steiner Verlag Wiesbaden GmbH, 1987.

Hölkeskamp, K.-J. "Conquest, Competition and Consensus. Roman Expansion in Italy and the Rise of the Nobilitas." Historia 42 (1993), 12-39.

Hölkeskamp, K.-J. "Fides-deditio in fidem-dextra data et accepta: Recht, Religion und Ritual in Rom" ["Law, Religion and Ritual in Rome"]. In The Roman Middle Republic. Politics, Religion, and Historiography c. 400-133 BC. Rome: Institutum Romanum Finlandiae, 2000, 223-250.

Hölkeskamp, K.-J. Rekonstruktionen einer Republik [Reconstructions of a Republic]. München: Oldenbourg Wissenschaftsverlag GmbH, 2004.

Kehne, P. "Geiselstellungen im römischen Völkerrecht und der Außenpolitik des Prinzipats" ["Hostage Delivering in Roman International Law and in Foreign Policy under the Principate"]. Marburger Beiträge zur Antiken Handels-, Wirtschafts- und Sozialgeschichte 30 (2012), 199-254.

Klotz, A. Livius und seine Vorgänger [Livy and his Predecessors] 1. Stuttgart: Verlag B.G. Teubner, 1940.

Matthaei, A. "Das Geiselwesen bei den Römern" ["Roman Use of Hostages"]. Philologus 64 (Jan. 1905), 224-247.

Mehl, A. "Eumenes II. Soter." In Der Neue Pauly 4, s.v. Eumenes, 1998, 251-253.

Moscovich, M. J. The Role of Hostages in Roman Foreign Policy. Open Access Dissertations and Theses. Paper 7770. McMaster University, 1972.

NDiaye, S. "Le recours aux otages à Rome sous la République" ["The Use of Hostages in Republican Rome"]. In Dialogues d' Histoire Ancienne 21, no. 1 (1995), 149165.

Nörr, D. Aspekte des römischen Völkerrechts. Die Bronzetafel von Alcántara [Aspects of Roman International Law. The Bronze Plaque of Alcántara]. München: Verlag der Bayerischen Akademie der Wissenschaften, 1989.

Pfiffig, A. J. "Die Haltung Etruriens im 2. punischen Krieg" ["The Position of Etruria during the Second Punic War"]. Historia 15 (1966), 193-210.

Rich, J. W. "Treaties, allies and the Roman conquest of Italy." In War and Peace in Ancient and Mediaeval History, edited by Philip de Souza. New York, NY: Cambridge University Press, 2008, 51-75. 
Scolnic, B. "Antiochus IV and the Three Horns in Daniel 7." Journal of Hebrew Scriptures 14 (2014), 1-28.

Täubler, E. Imperium Romanum. Studien zur Entwicklungsgeschichte des Römischen Reichs 1: Die Staatsverträge und Vertragsverhältnisse [Studies in the Development of the Roman Empire 1: Treaties and Contractual Relationships]. Leipzig: Teubner, 1964 (1913).

Walker, C. L. "Hostages in Republican Rome." PhD diss., University of North Carolina at Chapel Hill, 1980.

Ziegler, K.-H. "Völkerrecht der Römischen Republik" [International Law of the Roman Republic]. In Aufstieg und Niedergang der Römischen Welt I, 2, edited by Temporini, Hildegard. de Gruyter, Berlin/New York, 1972, 68-114. 
